\title{
Subdivision of molecularly-classified groups by new gene signatures in breast cancer patients
}

\author{
ATHANASIOS ARMAKOLAS ${ }^{1}$, GEORGE P. STATHOPOULOS ${ }^{2}$, ADRIANOS NEZOS ${ }^{1}$, \\ APOSTOLOS THEOS $^{1}$, MARTHA STATHAKI ${ }^{1}$ and MICHAEL KOUTSILIERIS ${ }^{1}$ \\ ${ }^{1}$ Laboratory of Experimental Physiology, Medical School, National and Kapodestrian University of Athens, \\ Athens 11527; ${ }^{2}$ First Oncology Clinic, Errikos Dunant Hospital, Athens 11526, Greece
}

Received March 9, 2012; Accepted May 7, 2012

DOI: $10.3892 /$ or.2012.2018

\begin{abstract}
Gene expression patterns as well as gene interactions are under investigation for their involvement in tumour heterogeneity. The molecular classification of breast cancer based on hormone receptor expression, grade and HER2 receptor levels, is indicative but not adequate enough to complete the prognostic data. The objectives of this study were to validate the prognostic value of 19 genes, solely, and as parts of classifiers (sets of genes), in breast cancer patients and to determine whether the expression of these genes and classifiers is correlated with breast cancer molecular classification. Gene expression was examined in the blood of 88 breast cancer patients and 50 healthy controls using multiplex quantitative real-time PCR. Patients with a second primary malignancy showed a statistically significant difference when compared with: i) patients with a single breast cancer, for an 8-gene classifier $(\mathrm{P}<0.02)$; and ii) healthy individuals (classifier FBX033, FLJ339115) $(\mathrm{P}<0.01)$, with respect to gene expression. The classifier ENY2, USP38 was associated with the development of primary breast cancer. A newly established classifier (ENY2, USP38, RPS7, Osbpl-1 and ETF1) indicated a statistically significant association with HER2 subtype patients, compared to patients with a different molecular classification $(\mathrm{P}<0.04)$. The gene FLJ33915 was differentially expressed in a subgroup of HER2-positive patients with infiltrated axillary lymph nodes $(\mathrm{P}<0.028)$. We validated the prognostic value of 4 classifiers for primary and second primary malignancy. Evidence of a classifier predicting the HER2 subtype and the
\end{abstract}

Correspondence to: $\operatorname{Dr}$ Athanasios Armakolas, Laboratory of Experimental Physiology, Medical School, National and Kapodestrian University of Athens, Mikras Asias 75, Athens 11527, Greece

E-mail: aarmakol@med.uoa.gr

Dr George P. Stathopoulos, Semitelou 2A, Athens 11528, Greece E-mail:dr-gps@ath.forthnet.gr

Key words: breast cancer, real-time RT-PCR, HER2 subtype patients gene FLJ33915 which subdivides HER2 subtype patients is also presented.

\section{Introduction}

Breast cancer is one of the most common malignancies affecting women, with a lifetime risk of about 1 in 10. Breast cancer is considered both genetically and histopathologically heterogeneous (1). The mechanisms underlying breast cancer progression remain undetermined and are under investigation. The major prognostic characteristics for this disease have been based on conventional prognostic indicators, such as lymph node status, oestrogen receptor status, c-erb2 gene, tumour size and histological grade. However, it is still difficult to determine an accurate patient prognosis. Genetic expression (gene signatures) provides the basis for improving the molecular classification of breast cancer (2). Recently, an effort has been made to correlate the tumour characteristics of the patient with certain gene signatures. A classification scheme provides a very important framework for the study of breast cancer. The new form of classification represents four molecular subtypes with clinically distinct behaviour, that perhaps arise from different precursor cells in the breast. The true prognostic value of the various molecular classes is necessary because there is a strong correlation between molecular class and conventional histopathological variables. The subtypes of molecular classification are 4: Luminal A (positive hormone receptors, low grade), Luminal B (positive hormone receptors, high grade), HER2 positive subtype and Basal cell type (the latter of which includes triple negative patients) (3-5).

In order to explore the molecular basis of breast carcinogenesis aiming towards a more accurate prognosis and more effective therapeutic intervention, studies tend to focus on the microarray analysis of the whole transcriptome and proteome of the tumour, from the patients' blood $(1,6,7)$.

Profiles of transcription and translation have shown specific changes among different types of cancer as a result of sequential mutation and signal amplification, distinguishing cancers from normal tissues. Moreover, the different gene expression profiles are likely to reflect distinct tumour subtypes involving different phenotypes and clinical features (8-11). Changes in the expression level of cancer-related genes occur much earlier than morphological changes, and they lead to a different degree 
of cellular differentiation (12). A characteristic expression profile in the blood may contribute to cancer prognosis. New molecular tumour markers can potentially be used for more accurate classification and drug targets for effective personalized therapy (13-19). The predictive power of these approaches is much greater than that of the currently used approaches based on the tumour characteristics, but this remains to be validated in prospective clinical studies.

The objective of the present study was to evaluate the predictive power of five sets of genes previously found to be correlated with primary breast cancer and second primary malignancies in breast cancer patients (17) and to determine whether the deregulation of these genes is correlated with breast cancer molecular classification.

\section{Materials and methods}

Patients. Blood was collected from 88 breast cancer patients with a 3-10 year follow-up after primary tumour excision. Blood was also collected from 50 age-matched healthy volunteers. The protocol was approved by the Ethics Committee of the Errikos Dynant Hospital and informed consent was signed by all the patients and healthy individuals participating in the study.

Eligibility for the study required histologically-confirmed breast cancer, including patients of all stages with a World Health Organization (WHO) performance status of 0-2. All patients had been treated with surgery, chemotherapy and/or endocrine treatment and/or radiotherapy. Before enrollment in the study the patients were clinically evaluated.

Staging was determined by chest and abdominal CT scans, bone scans and occasionally, MRIs. All patients had normal liver and renal function tests. The patients were divided on the basis of their histopathological characteristics and the molecular classification subgroups. All of the clinicopathological characteristics (age, stage, histological grade, tumour size, metastasis and lymph node involvement) are shown in Table I.

Gene selection. The 19 genes investigated were selected on the basis of their association with primary breast cancer and with the development of second primary tumours in breast cancer patients (17). These genes were part of 4 classifiers genes: i) FLJ38663, LOC34563, MTRF1L, COMMD1, C10ORF22, STARD7, BAG3 and SNX26; ii) RPS7, OSBPL1, ETF1; iii) FBX033, FLJ339115; and iv) ENY2, USP38) (Table II). In addition, the genes HNRPC, SET, HSPE1 and HCG2040681 were tested although they were not categorised as a classifier. The downregulation of these genes was statistically significantly correlated with single and second primary cancer development $(\mathrm{P}<0.00001)$ (Table II). Two endogenous housekeeping genes (18S and $\beta$-actin) were included and were used to normalize the expression levels of the other genes.

RNA isolation. Total RNA was isolated from freshly collected blood after discarding the first $3 \mathrm{ml}$ beforehand, in order to avoid epithelial cell contamination. RNA concentration and quality were examined spectrophotometrically (BioSpec Nano, Shimantzu, Japan) and by agarose gel electrophoresis. RNA extraction was obtained using TRI-Reagent (MRC) according to the manufacturer's instructions.
Table I. Clinicopathological data of patients.

\begin{tabular}{lcc}
\hline Characteristics & $\begin{array}{c}\text { Patients } \\
(\mathrm{n}=88)\end{array}$ & $\begin{array}{c}\text { Healthy } \\
\text { individuals (n=50) }\end{array}$ \\
\hline Age (years), median (range) & 57.2 & 55.7 \\
& $40-74$ & $38-65$ \\
Tumour size (cm) & & \\
$<2$ & 40 & \\
$\geq 2-<5$ & 40 & \\
$\geq 5$ & 8 & \\
Histological grade & & \\
I & 15 & \\
II & 38 & \\
III & 35 & \\
Stage & & \\
I & 12 \\
II & 33 \\
III & 26 \\
IV & 17 \\
Metastasis & 17 \\
ER status positive & 66 \\
PR status positive & 43 \\
HER2 status positive & 25 \\
Lymph node status & 38 \\
Molecular classification & \\
Luminal A & 27 \\
Luminal B & 26 \\
HER2 subtype & 25 \\
Basal-like tumours & 10 \\
Second primary development & 14 \\
\hline
\end{tabular}

qRT-PCR. The examination of the expression levels of the 19 genes was obtained by multiplex quantitative-real time PCR (qRT-PCR): primer set, probes and PCR conditions used in each case were selected using the software Beacon Designer 7.0 (Premier Biosoft International). The primers were further examined using the FastPCR software and by carrying out NCBI blast (Table III). Prior to the multiplex qRTPCR analysis, these 19 genes were separated into 4 sets that were designed in such a way that led to the compatibility amongst the primers, probes and fluorophores in each reaction. The primer, probe and fluorophore compatibility for each multiplex set was examined and approved by Bio-Rad Laboratories (Table III). Each RT reaction was carried out using $1 \mu \mathrm{g}$ of RNA with an iScript cDNA synthesis kit (Bio-Rad Laboratories) according to the manufacturer's instructions. The obtained cDNA was amplified by multiplex qRT-PCR. Prior to the original experiment, each RT-PCR product was examined by enzyme digest and sequencing. Each reaction was obtained in $25 \mu \mathrm{l}$ using 12.5 $\mu \mathrm{l}$ IQ Multiplex Powermix (Bio-Rad Laboratories), $2 \mu \mathrm{l}$ cDNA, $0.3 \mu \mathrm{M}$ of each primer and $0.2 \mu \mathrm{M}$ of each probe. In each case $18 \mathrm{~S}$ and $\beta$-actin were used as internal controls. Each reaction was performed in duplicate for each patient. The validation of the product 
Table II. Multiplex qRT-PCR analysis.

\begin{tabular}{|c|c|c|c|}
\hline Multiplex set & Gene & Classifier & $\begin{array}{c}\text { PCR conditions } \\
\left.\text { (1st cycle at } 95^{\circ} \mathrm{C} \text { for } 3 \mathrm{~min}\right)\end{array}$ \\
\hline 1 & $\begin{array}{l}\text { C10ORF22 } \\
\text { COMMD1 } \\
\text { MTRF1L } \\
\text { STARD7 }\end{array}$ & $\begin{array}{l}1 \\
1 \\
1 \\
1\end{array}$ & $\begin{array}{l}95^{\circ} \mathrm{C} \text { for } 15 \mathrm{sec} \\
58^{\circ} \mathrm{C} \text { for } 1 \mathrm{~min}, \mathrm{x} 40 \text { cycles }\end{array}$ \\
\hline 2 & $\begin{array}{l}\text { BAG3 } \\
\text { SNX26 } \\
\text { LOC345630 }\end{array}$ & $\begin{array}{l}1 \\
1 \\
1\end{array}$ & $\begin{array}{l}95^{\circ} \mathrm{C} \text { for } 15 \mathrm{sec} \\
56^{\circ} \mathrm{C} \text { for } 1 \mathrm{~min}, \mathrm{x} 40 \text { cycles }\end{array}$ \\
\hline 3 & $\begin{array}{l}\text { FLJ38663 } \\
\text { FBX033 } \\
\text { FLJ33915 }\end{array}$ & $\begin{array}{l}1 \\
2 \\
2\end{array}$ & $\begin{array}{l}95^{\circ} \mathrm{C} \text { for } 15 \mathrm{sec} \\
58^{\circ} \mathrm{C} \text { for } 1 \mathrm{~min}, \mathrm{x} 40 \text { cycles }\end{array}$ \\
\hline 4 & $\begin{array}{l}\text { HNRPC } \\
\text { SET } \\
\text { HSPE1 } \\
\text { HCG2040681 }\end{array}$ & & $\begin{array}{l}95^{\circ} \mathrm{C} \text { for } 15 \mathrm{sec} \\
57^{\circ} \mathrm{C} \text { for } 1 \mathrm{~min}, \mathrm{x} 40 \text { cycles }\end{array}$ \\
\hline 5 & $\begin{array}{l}\text { RPS7 } \\
\text { OSBPL1 } \\
\text { ETF1 }\end{array}$ & $\begin{array}{l}3 \\
3 \\
3\end{array}$ & $\begin{array}{l}95^{\circ} \mathrm{C} \text { for } 15 \mathrm{sec} \\
57^{\circ} \mathrm{C} \text { for } 1 \mathrm{~min}, \mathrm{x} 40 \text { cycles }\end{array}$ \\
\hline 6 & $\begin{array}{l}\text { ENY2 } \\
\text { USP38 } \\
\text { ACTB } \\
18 S\end{array}$ & $\begin{array}{l}4 \\
4\end{array}$ & $\begin{array}{l}95^{\circ} \mathrm{C} \text { for } 5 \mathrm{sec} \\
58^{\circ} \mathrm{C} \text { for } 1 \mathrm{~min}, \mathrm{x} 40 \text { cycles }\end{array}$ \\
\hline
\end{tabular}

Six gene sets were obtained, each one composed from 2 to 4 genes; here the PCR conditions used for the analysis of each gene set are also described.

identity and expression was obtained by the melting curve. We used a two-step amplification reaction according to the manufacturer's instructions (Table II) using the IQ5 thermal cycler (Bio-Rad Laboratories).

We analysed the data with the LightCycler software. Briefly, three serial 10-fold dilutions of cDNA from 50 normal individuals were amplified in duplicates to construct standard curves and to set the baseline. Standard curves generated by the software were used for extrapolation of the expression level for the unknown samples based on their threshold cycle $(\mathrm{Ct})$ values. For each reaction, melting curves and agarose gel electrophoresis of PCR products, enzyme digests and sequencing, were used to verify the identity of the amplification products. All experiments were performed with at least two independent PCR reactions.

Statistical analysis. In our study, the gene expression of the 50 healthy individuals was set as the normal baseline. A gene was considered to be significantly differentially expressed (over- or underexpressed), if the ratio of the expression level in the cancer sample to the expression level in the blood of healthy individuals was higher than 4.0, which indicated a 4-fold increase in expression, or if the ratio was lower than 0.3 . The results obtained by real time RT-PCR for each gene and patients' clinopathological data, molecular staging and second primary tumour development were analysed using Multivariate Analysis of Variance (MANOVA). When significant differences were observed, discriminant function analysis was used to assess the relative contribution of each dependent variable. Each group of genes was considered the independent variable, while the patients' clinicopathological data, molecular staging and development of a second primary tumour were the dependent variables. All statistical analyses were performed using SPSS software for Windows (SPSS Inc., Chicago, IL) and a P-value of $<0.05$ was considered to be statistically significant.

\section{Results}

The molecular classification subgroups of patients (Luminal A, B, HER2 subtype and Basal) were compared for gene deregulation levels of the classifiers and of each gene solely. MANOVA for the five-gene classifier ENY2, USP38, RPS7, OSBPL1 and ETF1 revealed a statistically significant difference between HER2 subtype patients and the rest of the molecular subgroups (Wilks' lambda: 0.85, F=2.42, $\mathrm{P}<0.04$ ). Discriminant analysis indicated that ETF1 is the most important gene predictor, separating the HER2 subtype from the rest of the subtypes, (Wilks' lambda: 0.93, $\mathrm{F}=5.32, \mathrm{P}<0.02$ ). Furthermore, FLJ33915 gene expression was found to differ 
Table III. Primers, probes and fluorophores for each gene, used in multiplex qRT-PCR.

\begin{tabular}{|c|c|c|c|}
\hline Gene & Primer & Probe & Fluorophore \\
\hline C10ORF22 & $\begin{array}{l}\text { F: GCCGGGACTGCCACTATTAC } \\
\text { R: AGACCTTGGGACCTGGATAGG }\end{array}$ & TCCCTCGCACCAGAAGTCATCGGC & $\begin{array}{l}\text { 5'Texas Red } \\
\text { 3'BHQ2 }\end{array}$ \\
\hline STARD7 & $\begin{array}{l}\text { F: ATCCAATGTACTCACGGGATTATG } \\
\text { R: ATATGATCTGACCCTGACGAATTC }\end{array}$ & CACTCGGATGCTCCACAGCACGC & $\begin{array}{l}5^{\prime} \mathrm{Cy} 5 \\
\text { 3'BHQ3 }\end{array}$ \\
\hline MTRF1L & $\begin{array}{l}\text { F: GGCTCATTAAATCAGTTATGGTTCC } \\
\text { R: CAGCACTGTCCGTGGTATTTAC }\end{array}$ & CCCAGCTCCACTGGCTCGCTTAGT & $\begin{array}{l}\text { 5'FAM } \\
\text { 3'BHQ1 }\end{array}$ \\
\hline COMMD1 & $\begin{array}{l}\text { F: ACATCTGACCAAGCTGCTGTC } \\
\text { R: GCTGAGTGCCTTGACTGAGAC }\end{array}$ & ATCAACTCTCCAGCTCAGGCCCCG & $\begin{array}{l}5 \text { 'HEX } \\
\text { 3'BHQ1 }\end{array}$ \\
\hline BAG3 & $\begin{array}{l}\text { F: CTCAGAGGTCCCAGTCACC } \\
\text { R: GAGGAGGATGAGGATGAGCAG }\end{array}$ & CATGCCAGAAACCACTCAGCCAGA & $\begin{array}{l}\text { 5'FAM } \\
\text { 3'BHQ1 }\end{array}$ \\
\hline SNX26 & $\begin{array}{l}\text { F: TGGTGGTGGAGTTTCTGCTC } \\
\text { R: CTTCCTCCAGCGTCAGCAG }\end{array}$ & CCTGTTCAGCGACACCTTCACCTC & $\begin{array}{l}\text { 5'HEX } \\
\text { 3'BHQ1 }\end{array}$ \\
\hline FLJ38663 & $\begin{array}{l}\text { F: CATGGGGACTCCGGCTTTG } \\
\text { R: CTTCGAGTTCATTCTCATCCAAGG }\end{array}$ & AGGGTAGTCCTTCTTGCCTGCCAT & $\begin{array}{l}\text { 5'Texas Red } \\
\text { 3'BHQ2 }\end{array}$ \\
\hline LOC345630 & $\begin{array}{l}\text { F: GCCACTTTCTCATCTCCATCAAG } \\
\text { R: TCATAGGGCTCCAGGGTCAG }\end{array}$ & TCCACCGCATCCGCCGAGG & $\begin{array}{l}5 ' \mathrm{Cy} 5 \\
3 \text { 'BHQ3 }\end{array}$ \\
\hline FBX033 & $\begin{array}{l}\text { F: GGGACTGGAGGGGAGGAAG } \\
\text { R: AACTTCTGAAGGTTCCTGTTGTTC }\end{array}$ & ACCAGCACGCAAAGCACCAGC & $\begin{array}{l}\text { 5'HEX } \\
\text { 3'BHQ1 }\end{array}$ \\
\hline FLJ33915 & $\begin{array}{l}\text { F: GCCCAGGCGAGGTGGAAGG } \\
\text { R: GACCAGGGACGCTCGATTTC }\end{array}$ & ACGTCTGCCTCAGCCTGCTCG & $\begin{array}{l}\text { 5'FAM } \\
\text { 3'BHQ1 }\end{array}$ \\
\hline HNRPC & $\begin{array}{l}\text { F: GGCTTCAATTCTAAGAGTGGACAG } \\
\text { R: TCCAGGTTTTCCAGGAGAGAATC }\end{array}$ & TGGGTCAGCTCCTTCTTAATGGCCT & $\begin{array}{l}\text { 5'FAM } \\
\text { 3'BHQ1 }\end{array}$ \\
\hline SET & $\begin{array}{l}\text { F: GAAATATAACAAACTCCGCCAACC } \\
\text { R: AATTCTGTCACTTCAACTCTGGTC }\end{array}$ & CAGTGCCTCTTCATCTTCCTCCСCA & $\begin{array}{l}\text { 5'HEX } \\
\text { 3'BHQ1 }\end{array}$ \\
\hline HSPE1 & $\begin{array}{l}\text { F: TTGAAAGGAGTGCTGCTGAAAC } \\
\text { R: CACGCTAACTGGTTGAATCTCTC }\end{array}$ & AGAACCCGATCCAACAGCGACTACT & $\begin{array}{l}\text { 5'Texas Red } \\
\text { 3'BHQ2 }\end{array}$ \\
\hline HCG2040681 & $\begin{array}{l}\text { F: TGCAGGAGTTTAAAACGAGAGTG } \\
\text { R: CCCATCCAGTGACTTTGCTTTAG }\end{array}$ & TCCTTCCCTTTGCCTGTGGTGTCA & $\begin{array}{l}5 ' \mathrm{Cy} 5 \\
3 \text { 'BHQ3 }\end{array}$ \\
\hline RPS7 & $\begin{array}{l}\text { F: TCTTCTGGAGCTGGAGATGAAC } \\
\text { R: TGAGGAACGGGAACAAAGATTATG }\end{array}$ & AGCTTTCCGACCACCACCAACTTC & $\begin{array}{l}\text { 5'FAM } \\
\text { 3'BHQ1 }\end{array}$ \\
\hline OSBPL1 & $\begin{array}{l}\text { F: GAGTGGGGAGAAGCTGAAGG } \\
\text { R: CTGCCATTTCCGACTGTGTATC }\end{array}$ & ССАСССТСТTCCGCATCACATCC & $\begin{array}{l}\text { 5'HEX } \\
\text { 3'BHQ1 }\end{array}$ \\
\hline ETF1 & $\begin{array}{l}\text { F: AGGAGGAGGCGAGAAGATGG } \\
\text { R: GAAATCTGGTCTTTGGGAGGAATG }\end{array}$ & ACGACCCCAGTGCTGCCGAC & $\begin{array}{l}\text { 5'Texas Red } \\
\text { 3'BHQ2 }\end{array}$ \\
\hline ENY2 & $\begin{array}{l}\text { F: GTAACGGTCCTCAGCGCAAG } \\
\text { R: AACTTTTGGTTAATCGCTGCTCTC }\end{array}$ & CATCTTGCTAACCACCATCACCGCG & $\begin{array}{l}\text { 5'FAM } \\
\text { 3'BHQ1 }\end{array}$ \\
\hline USP38 & $\begin{array}{l}\text { F: CAGCATCTTTTTGCCTTTCTGG } \\
\text { R: CTGAGGTATTCAGAACAGTCTTGC }\end{array}$ & ACACAGAGGGAAGCATACGCACCT & $\begin{array}{l}\text { 5'HEX } \\
\text { 3'BHQ1 }\end{array}$ \\
\hline АCTB & $\begin{array}{l}\text { F: GCACAGAGCCTCGCCTTTG } \\
\text { R: CATGCCGGAGCCGTTGTC }\end{array}$ & CCGCCGCCCGTCCACACC & $\begin{array}{l}\text { 5'Texas Red } \\
\text { 3'BHQ2 }\end{array}$ \\
\hline $18 \mathrm{~S}$ & $\begin{array}{l}\text { F: GGCTCATTAAATCAGTTATGGTTCC } \\
\text { R: CGGGTTGGTTTTGATCTGATAAATG }\end{array}$ & TGGTCGCTCGCTCCTCTCCTACT & $\begin{array}{l}5 ' \mathrm{Cy} 5 \\
\text { 3'BHQ3 }\end{array}$ \\
\hline
\end{tabular}

For each reaction, compatible fluorophores were used. BHQ, Black Hole Quencher.

significantly in lymph node positive HER2 subtype patients vs. lymph node negative HER2 subtype patients $(0.35 \pm 0.08$ and $0.63 \pm 0.08$, respectively, $\mathrm{P}<0.028$ ) (Table IV). None of the other genes or classifiers of genes examined in this study were statistically significantly correlated with any molecular classification subtype. 

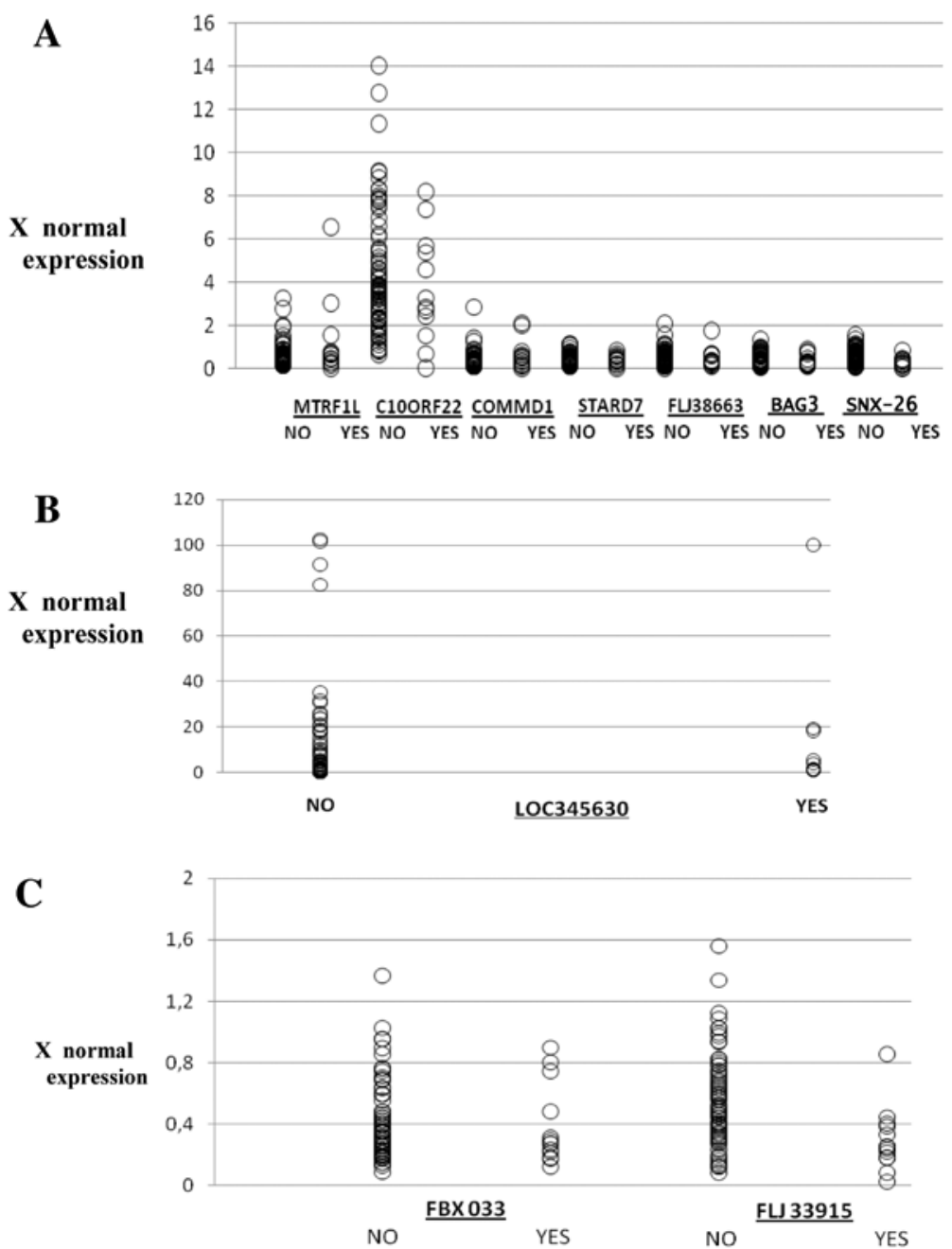

Figure 1. (A) The mRNA levels (times to normal expression) of MTRF1L, C10ORF22, COMMD1, STARD7, FLJ38663, BAG3, SNX26 and LOC345630, in patients negative (NO) or positive (YES) to the development of second primary malignancies using real-time RT-PCR. Each circle represents a patient. (B) Although we changed the scale for LOC345630 expression, three patients with very high values have not been included in this representation. Furthermore, it should ne noted that although there is little difference in the expression of each of these genes between individuals with a single cancer and individuals with a second primary tumour, together as a classifier, they represent a very useful tool for the determination of single breast cancer individuals susceptible to developing a second primary tumour. (C) The mRNA levels (times to normal expression) of FBX033 and FLJ33915 in patients negative (NO) or positive (YES) to the development of second primary malignancies using real-time RT-PCR.

Table IV. Association of genes and classifiers with a second primary malignancy and HER2 subgrouping.

\begin{tabular}{|c|c|c|c|}
\hline Classifier & Genes & Function & Statistical significance (P-value) \\
\hline First & $\begin{array}{l}\text { FLJ38663, LOC34563, MTRF1L, } \\
\text { COMMD1, C10ORF22, STARD7, } \\
\text { BAG3, SNX26 }\end{array}$ & $\begin{array}{l}\text { Second primary tumour predictor } \\
\text { (single tumour vs. second primary) }\end{array}$ & $<0.02$ \\
\hline Third & FBX033, FLJ339115 & $\begin{array}{l}\text { Second primary tumour predictor } \\
\text { (single tumour vs. normal) }\end{array}$ & $<0.01$ \\
\hline Fifth & $\begin{array}{l}\text { ENY2, USP38, RPS7, OSBPL1, } \\
\text { ETF1, FLJ33915 }\end{array}$ & $\begin{array}{l}\text { HER2 subtype predictor } \\
\text { HER2 subtype subgrouping } \\
\text { (with and without lymph node infiltration) }\end{array}$ & $<0.028$ \\
\hline
\end{tabular}

The two-gene classifiers ENY2 and USP38 were observed to be differentially expressed in breast cancer patients when compared to healthy individuals. Using descriptive statistics we found that $85 / 88$ patients $(95.6 \%)$ presented ENY2 expres- sion levels lower than 0.4 of the normal expression levels and $70 / 88$ patients presented USP38 expression at levels lower than 0.4 of the normal expression. In addition, we also observed that 72/88 patients (81.8\%) presented C10ORF $>3,86 / 88(97.7 \%)$ 
Table V. Description of the genes included in our study and their association with cancer.

Gene Function Cancer involvement

HCG2040681 Unclassified gene

FBXO33 Protein-ubiquitin ligase; F-box proteins interact with SKP1 through the $\mathrm{F}$ box, and they interact with ubiquitination targets through other protein interaction domains and mediate the ubiquitination and subsequent proteasomal degradation of target proteins (UPP) (20)

FLJ38663 Nuclear gene encodes a mitochondrial matrix protein that appears to contribute to peptide chain termination in the mitochondrial translation machinery; two different 1-bp deletions (resulting in the same premature stop codon) result in decreased mitochondrial translation, decreased levels of oxidative phosphorylation complexes and encepthalomyopathy; alternative splicing results in multiple transcript variants (21)

ENY2 Component of the transcription regulatory histone acetylation (HAT) complex SAGA, a multiprotein complex that activates transcription by remodeling chromatin and mediating histone acetylation and deubiquitination; it may also participate in mRNA export and accurate chromatin positioning in the nucleus by tethering genes to the nuclear periphery; USP 38 ubiquitin specific peptidase which is involved in ubiquitin catabolism (22)

HNRPC Essential for mitochondrial protein biogenesis, together with CPN60; it binds to CPN60 in the presence of Mg-ATP and suppresses the ATPase activity of the latter (23)

SET Highly conserved nuclear phosphoprotein that is ubiquitously expressed $(24,25)$; SET has been suggested to regulate $\mathrm{G} 2 / \mathrm{M}$ and in transition by modulating cyclin B-CDK1 activity

HSPE1 Proangiogenetic growth factor functions together with VEGF

OSBPL1 Membrane-bound protein that binds oxysterols and may inhibit their cytotoxicity and, there are alternative transcriptional splice variants that have not have not yet been fully characterised (28)

RPS7 Ribosomal protein is a component of the 40S subunit; this protein belongs to the S7E family of ribosomal proteins; it is located in the cytoplasm; as is typical for genes encoding ribosomal proteins, there are multiple processed pseudogenes of this gene dispersed through the genome; in our case the RPS7 mRNA was induced up to 33 times more than the normal levels and it is believed to be a p53 MDM2 interaction modulator (29)

ETF1 Functions as an omnipotent translation termination factor, decoding all 3 stop codons (30)

BAG3 Promotes substrate release after binding to the Hsc70/Hsp70 ATPase domain and inhibits its chaperone activity (31)

C10ORF Human thiol dioxygenases include cysteine dioxygenase (CDO; MIM 603943) and cysteamine (2-aminoethanethiol) dioxygenase (ADO; EC 1.13.11.19); CDO adds 2 oxygen atoms to free cysteine, whereas ADO adds 2 oxygen atoms to free cysteamine to form hypotaurine (32)
Breast cancer

Overexpressed in solid tumours of the breast, stomach, uterus and rectum and in leukaemia (26)

Involved in the metastatic biology of ovarian cancer (27) 
Table V. Continued.

\begin{tabular}{|c|c|}
\hline Gene & Function \\
\hline COMMD1 & $\begin{array}{l}\text { Associated with copper homeostasis, NF- } \mathrm{BB} \text { signalling, and sodium } \\
\text { transport and in HIF-1 signalling; hypoxia-inducible factors (HIFs) also } \\
\text { regulate oxygen homeostasis, which control angiogenesis, erythropoiesis, } \\
\text { glycolysis and cell survival/proliferation under normal and pathological } \\
\text { conditions (33) }\end{array}$ \\
\hline STARD7 & $\begin{array}{l}\text { Unknown function; its existence is supported by mRNA and EST data; } \\
\text { the predicted gene product contains a region similar to the STAR-related } \\
\text { lipid transfer (START) domain, which is often present in proteins involved } \\
\text { in the cell signalling mediated by lipid binding; some transcripts occur } \\
\text { only in cancer cell lines (34) }\end{array}$ \\
\hline SNX26 & $\begin{array}{l}\text { This gene encodes a member of the sorting nexin family; members of this } \\
\text { family contain a phox (PX) domain, which is a phosphoinositide-binding } \\
\text { domain, and they are involved in intracellular trafficking; alternative splice } \\
\text { variants encoding different isoforms have been identified in this gene (35) }\end{array}$ \\
\hline USP38 & Ubiquitin specific peptidase is involved in ubiquitin catabolism (36) \\
\hline LOC345630 & Unclassified gene \\
\hline MTRF1L & $\begin{array}{l}\text { Mitochondrial peptide chain release factor directs the termination of } \\
\text { translation in response to the peptide chain termination codons UAA } \\
\text { and UAG (37) }\end{array}$ \\
\hline FLJ33915 & Hypothetical protein \\
\hline
\end{tabular}

and RPS7 $<0.21$ and $62 / 88$ patients $(70.5 \%)$ presented FBX033 expression $<0.3$. In all of the cases, 1 was considered as the normal expression level.

The 8-gene classifier (genes FLJ38663, LOC34563, MTRF1L, COMMD1, C10ORF22, STARD7, BAG3 and SNX26) was indicative of the development of second primary tumours after comparing individuals with a second primary malignancy vs. individuals with one primary malignancy, (Wilks' lambda: 0.83, F=2.61, P<0.02) (Table IV; Fig. 1A and B). The case was similar for the 2-gene classifier (FBX033 and FLJ339115), in the comparison of individuals with a second primary malignancy vs. healthy individuals. There was a statistically significant difference in the degree of deregulation (Wilks' lambda: 0.89, F=4.92, P<0.01) (Table IV, Fig. 1C).

\section{Discussion}

The 19 genes and the gene classifiers were examined in order to find correlations with the molecular classification subgroups. These genes and classifiers were also examined to determine the relationships between primary breast cancer and second primary cancer in breast cancer patients. The results of this study concur with those previously published (17), suggesting that the proposed gene classifiers may be an attractive candidate with prognostic value of breast cancer heterogeneity.

The three-gene classifier (RPS7, OSBPL1 and ETF1) that was found to be related to breast cancer development, may be of value as a prognostic marker. Deregulation in the expression of each of these three genes was observed only in breast cancer patients and not in the healthy individuals. The patients with second primary tumours presented downregulation of FBX033, FLJ339115 gene expression (2-gene classifier) which was not observed in healthy individuals.

The 8-gene classifier was useful for the prognosis of second primary tumours in breast cancer patients. Therefore, the prognostic value for second primary tumour development is directed at: i) the 2-gene classifier (FBX033 and FLJ339115) in healthy individuals and ii) the 8-gene classifier (genes FLJ38663, LOC34563, MTRF1L, COMMD1, C10ORF22, STARD7, BAG3 and SNX26) in breast cancer patients.

Out of the 19 genes examined here, three (HNRPC, SET and HSPE1), are known to be directly related to carcinogenesis. The remaining 16 are not directly associated with cancer development (20-24) (Table V). These genes are involved in certain pathways, such as $\mathrm{p} 53$ protein stabilisation, the ubiquitin proteosome pathway, angiogenesis, cell survival and proliferation, G2 to $\mathrm{M}$ transition and protein synthesis, where defects in each of these may lead, indirectly, to cancer development (25-37). Our data suggests that some of these genes, not solely but as parts of a classifier can be used for the prognosis of breast cancer. These results were observed after comparing gene deregulation between healthy individuals, breast cancer patients and breast cancer patients with a second primary tumour.

The 5-gene classifier (ENY2, USP38, RPS7, OSBPL1 and ETF1) deregulation presents a statistically significant 
difference between the HER2 subtype versus the rest of the subgroups of molecular classification. By further analysis, the ETF1 gene was conceived as the most important factor that is deregulated in the majority of patients categorised as the HER2 subtype. The fact that not all the patients with the HER2 subtype presented with significant deregulation of ETF1 may be an indication of its usefulness as a marker for the sub-grouping of the HER2 subtype group. Moreover, FLJ33915 downregulation was associated with lymph node infiltration in HER2 subtype patients. Prior to the classification of breast cancer patients into the 4 molecular classification subtypes (Luminal A, Luminal B, HER2 and Basal), some of the factors that were traditionally considered for the prognosis of the disease were not included; lymph node infiltration is one of them. The fact that FLJ33915 gene deregulation is statistically significantly associated with lymph node infiltration in patients with the HER2 subtype, suggests its potential usefulness in subdividing this subtype. This evidence is also an indication that perhaps it is wise to reconsider the evaluation of lymph nodes at least in patients with the HER2 subtype.

In conclusion, the findings summarises above suggest that the use of the genomic tests mentioned in this study may improve our ability to identify high-risk breast cancer patients prone to develop a second primary tumour and healthy individuals who may develop breast cancer. These patients may benefit from the prognostic power of the molecular signatures based on gene expression which is driven by genes that are not directly associated with cancer development. Instead, these genes are associated with tumour development and progression. Furthermore, we present evidence of a possible sub-categorisation of HER2 subtype patients, based on the expression profile of FLJ33915.

\section{Acknowledgements}

We would like to thank the patients that participated in this study.

\section{References}

1. Sotiriou C and Pusztai L: Gene-expression signatures in breast cancer. N Engl J Med 360: 790-800, 2009.

2. Oakman C, Santarpia L and Di Leo A: Breast cancer assessment tools and optimizing adjuvant therapy. Nat Rev Clin Oncol 7: 723-732, 2010.

3. Wirapati P, Sotiriou C, Kunkel S, Farmer P, Pradervand S, Haibe-Kains B, Desmedt C, Ignatiadis M, Sengstag T, Schütz F, et al: Meta-analysis of gene expression profiles in breast cancer: toward a unified understanding of breast cancer subtyping and prognosis signatures. Breast Cancer Res 10: R65, 2008.

4. Weigelt B, Hu Z, He X, Livasy C, Carey LA, Ewend MG, Glas AM, Perou CM and Van't Veer LJ: Molecular portraits and 70-gene prognosis signature are preserved throughout the metastatic process of breast cancer. Cancer Res 65: 9155-9158, 2005.

5. Parker JS, Mullins M, Cheang MC, Leung S, Voduc D, Vickery T, Davies S, Fauron C, He X, Hu Z, et al: Supervised risk predictor of breast cancer based on intrinsic subtypes. J Clin Oncol 27: $1160-1167,2009$.

6. Correa Geyer F and Reis-Filho JS: Microarray-based gene expression profiling as a clinical tool for breast cancer management: are we there yet? Int J Surg Pathol 17: 285-302, 2009.

7. Cosler LE and Lyman GH: Economic analysis of gene expression profile data to guide adjuvant treatment in women with earlystage breast cancer. Cancer Invest 27: 953-959, 2009.
8. Perou CM, Sorlie T, Eisen MB, van de Rijn M, Jeffrey SS, Rees CA, Pollack JR, Ross DT, Johnsen H, Akslen LA, et al: Molecular portraits of human breast tumours. Nature 406: 747-752, 2000

9. Feng Y, Li X, Sun B, Wang Y, Zhang L, Pan X, Chen X, Wang X, Wang $\mathrm{J}$ and Hao $\mathrm{X}$ : Evidence for a transcriptional signature of breast cancer. Breast Cancer Res Treat 122: 65-75, 2009.

10. Creighton CJ, Fu X, Hennessy BT, Casa AJ, Zhang Y, GonzalezAngulo AM, Lluch A, Gray JW, Brown PH and Hilsenbeck S: Proteomic and transcriptomic profiling reveals a link between the PI3K pathway and lower estrogen-receptor (ER) levels and activity in $\mathrm{ER}^{+}$breast cancer. Breast Cancer Res 12: R40, 2010.

11. Chernov AV, Baranovskaya S, Golubkov VS, Wakeman DR, Snyder EY, Williams R and Strongin AY: Microarray-based transcriptional and epigenetic profiling of matrix metalloproteinases, collagens, and related genes in cancer. J Biol Chem 285: 1964719659, 2010.

12. Sorlie T, Tibshirani R, Parker J, Hastie T, Marron JS, Nobel A, Deng S, Johnsen H, Pesich R, Geisler S, et al: Repeated observation of breast tumor subtypes in independent gene expression data sets. Proc Natl Acad Sci USA 100: 8418-8423, 2003.

13. Miecznikowski JC, Wang D, Liu S, Sucheston L and Gold D: Comparative survival analysis of breast cancer microarray studies identifies important prognostic genetic pathways. BMC Cancer 10: 573, 2010.

14. Chen H, Pimienta G, Gu Y, Sun X, Hu J, Kim MS, Chaerkady R, Gucek M, Cole RN, Sukumar S and Pandey A: Proteomic characterization of Her2/neu-overexpressing breast cancer cells. Proteomics 16: 3600-3610, 2010.

15. Tebbit CL,Zhai J, Untch BR, Ellis MJ, Dressman HK, Bentley RC, Baker JA, Marcom PK, Nevins JR, Marks JR and Olson JA Jr: Novel tumor sampling strategies to enable microarray gene expression signatures in breast cancer: a study to determine feasibility and reproducibility in the context of clinical care. Breast Cancer Res Treat 118: 635-643, 2009.

16. Centeno BA, Enkemann SA, Coppola D, Huntsman S, Bloom G and Yeatman TJ: Classification of human tumors using gene expression profiles obtained after microarray analysis of fineneedle aspiration biopsy samples. Cancer 105: 101-109, 2005.

17. Stathopoulos GP and Armakolas A: Differences in gene expression between individuals with multiple primary and single primary malignancies. Int J Mol Med 24: 613-622, 2009.

18. Sørlie T: Molecular classification of breast tumors: toward improved diagnostics and treatments. Methods Mol Biol 360: 91-114, 2007.

19. Sørlie T, Perou CM, Tibshirani R, Aas T, Geisler S, Johnsen H, Hastie T, Eisen MB, van de Rijn M, Jeffrey SS, et al: hnRNP C is required for postimplantation mouse development but Is dispensable for cell viability. Mol Cell Biol 20: 4094-4105, 2000.

20. Adachi Y, Pavlakis GN and Copeland TD: Identification and characterization of SET, a nuclear phosphoprotein encoded by the translocation break point in acute undifferentiated leukemia. J Biol Chem 269: 2258-2262, 1994.

21. Canela N, Rodriguez-Vilarrupla A, Estanyol JM, Diaz C, Pujol MJ, Agell N and Bachs O: The SET protein regulates G2/M transition by modulating cyclin B-cyclin-dependent kinase 1 activity. J Biol Chem 278: 1158-1164, 2003.

22. Ozbek U, Kandilci A, van Baal S, et al: SET-CAN the product of $\mathrm{t}(9 ; 9)$ in acute undifferentiated leukaemia, causes expansion of early haematopoietic progenitors and hyperproliferation of stomach mucosa in transgenic mice. Am J Pathol 171: 654-666, 2007.

23. Ralph S, Brenchley PE, Summers A, Rosa DD, Swindell R and Jayson GC: Heparanase gene haplotype (CGC) is associated with stage of disease in patients with ovarian carcinoma. Cancer Sci 98: 844-849, 2007.

24. Sørlie T, Perou CM, Tibshirani R, Aas T, Geisler S, Johnsen H, Hastie T, Eisen MB, van de Rijn M, Jeffrey SS, et al: Gene expression patterns of breast carcinomas distinguish tumor subclasses with clinical implications. Proc Natl Acad Sci USA 98: 10869-10874, 2001.

25. Lutz M, Wempe F, Bahr I, Zopf D and von Melchner H: Proteasomal degradation of the multifunctional regulator YB-1 is mediated by an F-Box protein induced during programmed cell death. FEBS Lett 580: 3921-3930, 2006.

26. Antonicka H, Ostergaard E, Sasarman F, Weraarpachai W, Wibrand F, Pedersen AM, Rodenburg RJ, van der Knaap MS, Smeitink JA, Chrzanowska-Lightowlers ZM and Shoubridge EA: Mutations in C12orf65 in patients with encephalomyopathy and a mitochondrial translation defect. Am J Hum Genet 87: 115-122, 2010. 
27. Sowa ME, Bennett EJ, Gygi SP and Harper JW: Defining the human deubiquitinating enzyme interaction landscape. Cell 138: 389-403, 2009.

28. Torrini M, Marchese C, Vanzetti M, Marini V, Origone P, Garré $\mathrm{C}$ and Mareni C: Mutation analysis of oxisterol-bindingprotein gene in patients with age-related macular degeneration. Genet Test 11: 421-426, 2007.

29. Chen D, Zhang Z, Li M, Wang W, Li Y, Rayburn ER, Hill DL, Wang $\mathrm{H}$ and Zhang R: Ribosomal protein S7 as a novel modulator of p53-MDM2 interaction: binding to MDM2, stabilization of p53 protein, and activation of p53 function. Oncogene 26: 5029-5037, 2007.

30. Costanzo M, Baryshnikova A, Bellay J, Kim Y, Spear ED, Sevier CS, Ding H, Koh JL, Toufighi K, Mostafavi S, et al: The genetic landscape of a cell. Science 22: 327: 425-431, 2010.

31. Doong H, Rizzo K, Fang S, Kulpa V, Weissman AM and Kohn EC: CAIR-1/BAG-3 abrogates heat shock protein-70 chaperone complex-mediated protein degradation: accumulation of poly-ubiquitinated Hsp90 client proteins. J Biol Chem 278: 28490-28500, 2003.
32. Du X, Nagata S, Ise T, Stetler-Stevenson M and Pastan I: FCRL1 on chronic lymphocytic leukemia, hairy cell leukemia, and B-cell non-Hodgkin lymphoma as a target of immunotoxins. Blood 111: 338-343, 2008.

33. Malek SN, Dordai DI, Reim J, et al: Malignant transformation of early lymphoid progenitors in mice expressing an activated Blk tyrosine kinase. Proc Natl Acad Sci USA 95: 7351-7356, 1998.

34. Tschumper RC, Geyer SM, Campbell ME, et al: Immunoglobulin diversity gene usage predicts unfavorable outcome in a subset of chronic lymphocytic leukemia patients. J Clinc Invest 118: 306-315, 2008.

35. Vitek L and Schwertner HA: The heme catabolic pathway and its protective effects on oxidative stress-mediated diseases. Adv Clin Chem 43: 1-57, 2007.

36. Mani A and Gelmann EP: The ubiquitin-proteasome pathway and its role in cancer. J Clin Oncol 23: 4776-4789, 2005

37. Yanagisawa M, Huveldt D, Kreinest $\mathrm{P}$, et al: $\mathrm{p} 120$ catenin isoform switch affects Rho activity, induces tumor cell invasion and predicts metastatic disease. J Biol Chem 283: 18344-18354, 2008 . 